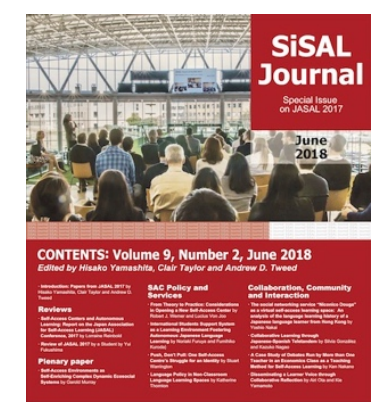

ISSN 2185-3762
Studies in Self-Access Learning J ournal

https://sisaljournal.org

ニコニコ動画が持つバーチャルなセルフアクセスラー ニングスペースとしての機能に関する考察〜香港出身 の日本語学習者の言語学習史をもとに〜

The Social Networking Service "Niconico Douga" as a Virtual Self-Access Learning Space: An Analysis of the Language Learning History of a J apanese Language Learner from Hong Kong

中井好男, 同志社大学日本語日本文化教育センター Yoshio Nakai, Doshisha University Center for J apanese Language and Culture, Japan

Corresponding author: uminchufunto@gmail.com

Publication date: J une, 2018.

To cite this article

Nakai, Y. (2018). The social networking service "Niconico Douga" as a virtual self-access learning space: An analysis of the language learning history of a J apanese language learner from Hong Kong. Studies in Self-Access Learning Journal, 92), 179-195.

To link to this article

https://sisaljournal.org/archives/jun18/nakai

This article may be used for research, teaching and private study purposes. Please contact the author for permission to re-print elsewhere. 
ニコニコ動画が持つバーチャルなセルフアクセスラーニングスペースと しての機能に関する考察〜香港出身の日本語学習者の言語学習史をもと に〜

\title{
The social networking service "Niconico Douga" as a virtual self-access learning space: An analysis of the language learning history of a Japanese language learner from Hong Kong
}

中井好男，同志社大学日本語日本文化教育センター

Yoshio Nakai, Doshisha University Center for Japanese Language and Culture, Japan

\section{要旨}

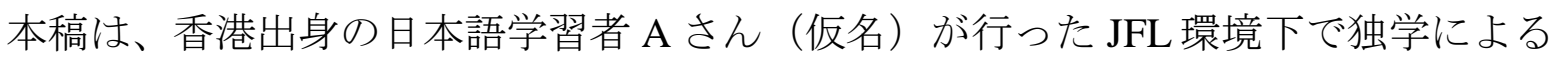
日本語学習に関する論考である。Aさんは香港では学校などでのフォーマルな日本 語教育を受けた経験がなく、日本語に興味を持った中学生のころからニコニコ動画 にアップロードされているゲームの実況動画やその生放送を用いて自力で日本語を 学んできた。Aさんはゲームを楽しむ、あるいは攻略方法を知るという目的を持っ た人たちが集まる実況動画や生放送の中から自身に合ったものを選択し、そこでの やり取りを理解してコメントを発信したり、Aさん自身がゲーム実況の生放送をし たりすることを通して日本語を学んできた。Aさんにとって、ニコニコ動画という 場は、ゲームに関する実践を通して日本語が学べる実践共同体であると同時に、自 身の目的や日本語レベルに合った動画や生放送が見られる保管庫でもあるバーチャ ルなセルフアクセスラーニングスペースとして機能していたことが分かった。

キーワード:日本語学習者、ニコニコ動画、インフォーマル・ラーニング、 学習者オートノミー、実践共同体、セルフアクセスラーニングスペース

\begin{abstract}
This article explores a language learning experience of a JFL (Japanese as a Foreign language) learner from Hong Kong who uses the social networking service "Niconico Douga". An analysis of her language learning history revealed that she not only utilized Niconico Douga as a resource bank for learning Japanese, but also that it functioned as a virtual self-access learning space. She learned Japanese language through watching and broadcasting live videos of playing computer games. Niconico Douga acts as a community of practice consisting of people who want to share and exchange information about playing digital games. She acquired Japanese language through practicing in the community of practice that allowed her to participate freely in special interest groups for playing digital
\end{abstract}


SiSAL Journal Vol. 9, No. 2, June 2018, 179-195.

games which offered the role models supporting her practice of broadcasting live videos of playing games. The features of Niconico Douga have a great potential for learning Japanese autonomously due to its accessibility and availability of resources.

Keywords: Japanese language learner, Niconico Douga, Informal learning, Learner autonomy, Community of practice, Self-access learning space

近年、インターネット上には、学習のために開発されたサイトや SNS などを 通じた他言語話者との交流の機会が溢れており、言語学習の内容や形式が非常に多 様化している。筆者がこれまで関わってきた日本語学習者の間でも、アニメやドラ マ、漫画、ライトノベルなどを用いた独学による自律的な日本語学習を経験してい る人が増加している。本研究を始めたのも、ニコニコ動画を用いて独学で日本語を 身につけた香港出身の学習者 $\mathrm{A}$ さん（仮名）に出会ったのがきっかけである。ニコ ニコ動画は動画を共有するサイトで、国内外問わずだれでもアクセスできる。サイ トには様々な動画がアップロードされており、動画は視聴するだけではなくコメン トをつけることもできる。また、ニコニコ生放送というものもあり、放送主がリア ルタイムで映像を流し、その視聴者であるユーザーが放送中にコメントをつけて楽 しむことができる。動画も生放送もコメントは放送画面の横に表示されるとともに 画面上を字幕のように流れる。特に生放送の場合、ユーザーのみならず動画の放送 主にもリアルタイムで共有されるため、放送主とユーザーとのリアルタイムなコミ ユニケーションが可能となっている（図 1 参照）。 


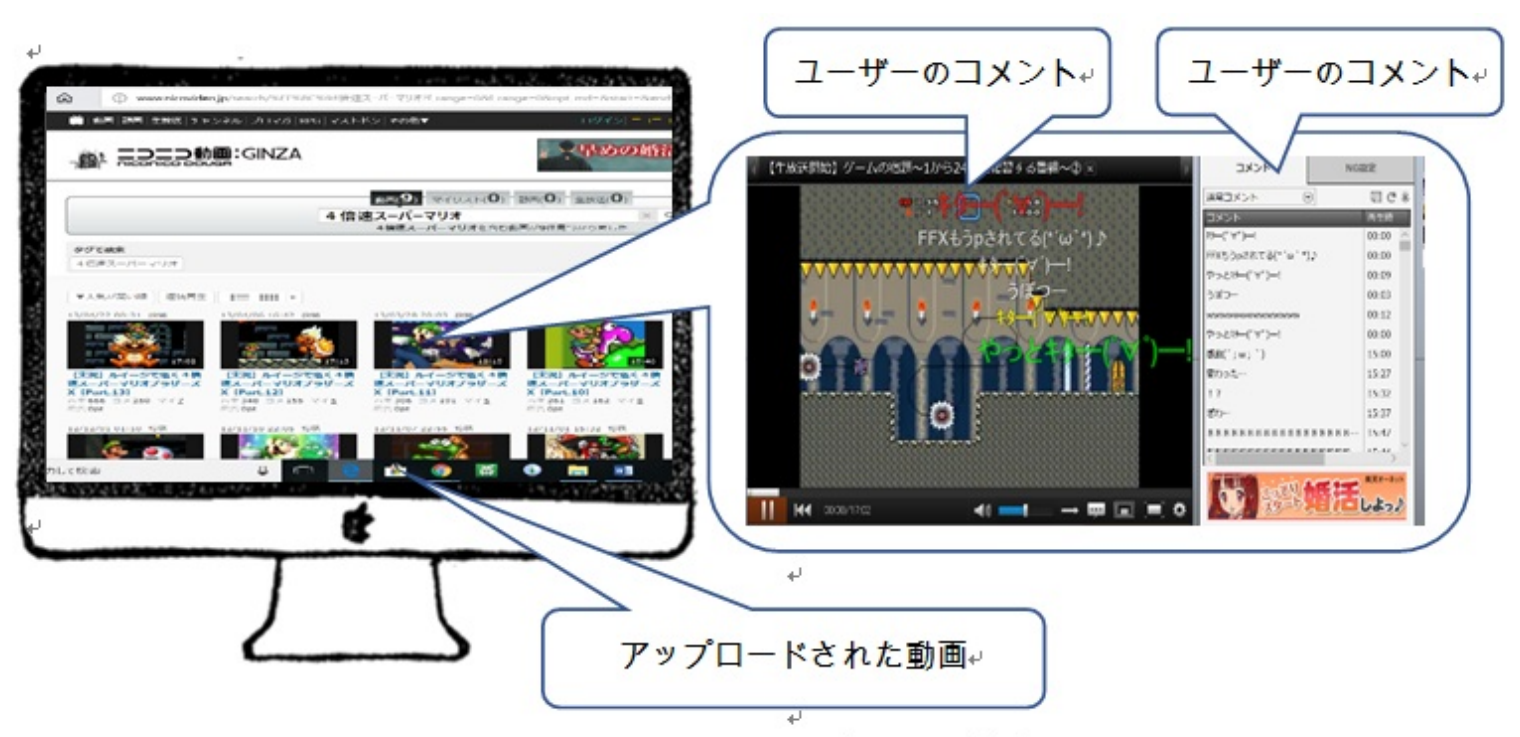

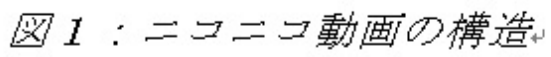

本研究は、このニコニコ動画を用いて日本語を学んだ A さんの学習経験をひ もとき、ニコニコ動画を日本語学習によ゙のように活用してきたのか、またそれを可 能にしたニコニコ動画はどのような特徵を持っているのかについて分析することを 目的とする。

\section{先行研究}

本研究では、ニコニコ動画を用いた A さんの日本語学習をインフォーマル・ ラーニングであると定義する。インフォーマル・ラーニングとは、学校などで進め られる構造化された学習ではなく、即興で生まれる活動を通して起こる学習（Cross, 2007）のことで、学習が起こる場所やその形態は多様であると言われている。幼い ころからニコニコ動画に慣れ親しんだ A さんのように、デジタル機器に囲まれて育 ってきた世代は「デジタルネイティブ（Prensky, 2001）」と呼ばれている。この世 代の学習者にとって、Facebook や Twitter などのソーシャルネットワーキングサービ ス（SNS）、オンラインゲームといったデジタルに関する実践は、彼らを取り巻く 社会を考える上で欠かせない構成要素の一つとなっており、言語学習にも注目すべ き影響を与えていることが明らかにされている(Benson \& Chik, 2010; Kárpáti, 2009; Peeters \& Ludwig, 2017)。先行研究では、ゲームプレイヤーがコミュニティサイトな どを通して情報交換をする例（Gee, 2004）やSNS で同じ興味・関心・目的を持つ人 
SiSAL Journal Vol. 9, No. 2, June 2018, 179-195.

たちがコミュニティを形成し、そこでのやり取りを通して学習を進めるといったも の(Kárpáti, 2009)、ゲームを通して言語を身につける例 (Chik, 2011)などが報告され ている。このように、SNSやゲームは共通の関心を持つ人たちが集まるコミュニテ イの形成を媒介しており、デジタルネイティブ世代にとってこのコミュニティは、 目的意識を持った人たちが集まり、絶え間ないインタラクションを通して知識を深 めたり専門性を高めたりしていく実践共同体（Wenger et al., 2002）や言語学習のプ ラットフォームとしての機能を備えているということが考えられる。

一方で、インフォーマル・ラーニングは学習者オートノミーに支えられてい ると言われている。学習者オートノミーというのは「自分の学習に関する意志決定 を自分で行なうための能力」である（青木・中田, 2011: 2）。学習を決めるカリキュ ラムや教師が介在しないインフォーマル・ラーニングは学習に関する意思決定を学 習者自身が行うことによって進められる。とりわけ、言語学習にもデジタルに関す る実践を用いるデジタルネイティブの場合、時間や場所を問わず様々なリソースに アクセスできるデジタル環境は学習の自律性をもたらす学習者オートノミーの発達 と関連していると言われている（Nunan \& Richard, 2015）。つまりコミュニティを 形成する SNS の一つであるニコニコ動画は、学習者が自由にアクセスできる言語学 習のリソースを提供する場であり、継続的な自律学習を可能にする側面を持ってい ると考えられる。

したがって、本研究では、ニコニコ動画が形成するインターネット上のコミ ユニティが、デジタルネイティブ世代の日本語学習のプラットフォームとしてどの ように用いられているのか、さらに学習を支える学習者オートノミーとどのように 関連しているのかを探る。これは、教室を対象とした研究が主流となっている言語 学習の研究（Benson \& Reinders, 2011）においても、言語学習支援や学習者オートノ ミ一の育成という文脈においても従来とは異なる視点をもたらす鍵となると考えら れる (Chik, 2018)。

\section{調查 - 分析方法}

本研究では、言語学習史（LLH：Language Learning History）を用いて A さん の日本語学習に関する経験を分析する。学習経験を振り返ることで意識や行動を記 述する言語学習史（Murphey et al., 2004）は、学習者にとっては自身の学習を内省す 
SiSAL Journal Vol. 9, No. 2, June 2018, 179-195.

る機会、教師や学習支援者にとっては直接目にすることができない教室外での学習 経験を知ることができるなど、指導や支援の在り方を検討する材料になるといった 利点がある。本研究では、経験の探索を可能にするライフストーリー（やまだ， 2000）の手法に従ってインタビューと分析を行った。インタビューは、2016 年 7 月 8 日（65 分）と 2016 年 7 月 22 日（48 分）の計 2 回実施した。インタビューにあた っては、本研究の目的と調査の方法を説明し、いつでもインタビューを中止できる こと、公開を望まない情報については研究には用いないことなどを説明し了承を得 ている。インタビューは半構造化インタビューの形式を取り、いつ日本語学習を始 めたのか、それはなぜなのか、どのように学習を進めたのかといった Aさんの学習 経験に関する質問を設定してインタビューを進め、さらに聞く必要があると思われ たことについては制限することなく広く聞き取りを行った。2回目のインタビュー では、1回目のインタビューで得られた情報を簡単にまとめたものを確認し内容の 訂正やさらに思い出したことなどを話し合った。インタビューはすべて日本語で行 い、IC レコーダーに録音した。分析の際はこの録音データを文字化し、Aさんが置 かれていた状況や A さんが取った行動を時系列に並べ、筆者との語り合いを通して 明らかになった Aさんの行動の理由やその意味をもとに言語学習史を作成した。完 成した言語学習史は $\mathrm{A}$ さんにその内容を確認してもらっている。言語学習史の内容 は、中学生のころから始めたニコニコ動画を用いた日本語学習、台湾の大学の日本 語学科での学習、日本の大学での学習という3つで構成されているが、本稿ではそ の中から、ニコニコ動画を用いた日本語学習の部分を取り上げる。

次に、本研究の研究協力者である Aさんについて紹介する。Aさんは香港出 身の 20 代の女性で、高校卒業後台湾の大学に進学し、2015 年 9 月に台湾の大学か らの交換留学生（当時 3 年生）として来日した。Aさんは香港ではフォーマルな日 本語教育を受けた経験がなく、日本語に興味を持った中学生のころからニコニコ動 画を用いて自力で日本語を学んできた。ニコニコ動画での学習を開始した当時はひ らがなやカタカナといった文字が読める程度であった。そして台湾の大学の日本語 学科に進学して初めて日本語教師に日本語を教わったということであった。 
SiSAL Journal Vol. 9, No. 2, June 2018, 179-195.

\section{ニコニコ動画を用いた $\mathbf{A}$ さんの日本語学習}

次に A さんの語りを引用する形で学習経験について記述する。Aさんの発言 をそのまま引用した箇所については「」で示しておく。

\section{ニコニコ動画を日本語学習に用いるようになった経緯}

A さんが日本語学習に関心を持ったのは、中学生のころ同級生である友人が 「日本語を勉強する塾」に通い始めたからであるが、A さんは経済的な理由から塾 に通うことはできなかった。そのため、当時「普通に暇つぶし」として見ていたゲ ーム実況のニコニコ動画を用いることにした。

「自分で 50 音だけが、50 音と、文法、確か、『が』、『は』、『て』、

『を』（助詞）、だけ知って、その後でニコ動（ニコニコ動画の略称、以下同様） 見て、どんどん勉強する。『が』、『は』、『て』、『を』、四つだけ。（中略） 確か、（スピードを４倍速にした）『マリオ』をやっている人の動画を見てて、あ の人、簡単な日本語しか言っていないので、ああじやあ私も分かるかな。」

A さんはニコニコ動画での日本語学習を始める前に、まず日本語を解説する サイトを用いて文字、簡単な文法と助詞を覚えた。その後、ゲームによっては日本 語が簡単であることに加え、「（Aさん自身が好きな）攵一ム解説があるし、日本 人もそこにいる」ため、ゲーム実況を学習に用いることにした。

\section{ニコニコ動画を用いた日本語学習の進め方}

次に、ゲーム実況の動画の利用方法について紹介する。Aさんの経験による と、日本語学習の方法には、視聴者という立場で行うものと生放送の放送主として

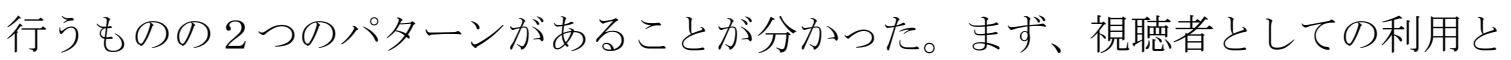
は、動画や生放送を選び、そこで話される日本語やリスナーとのやりとりを理解し コメントをするというものである。これには、動画や生放送の選択と動画の学習と

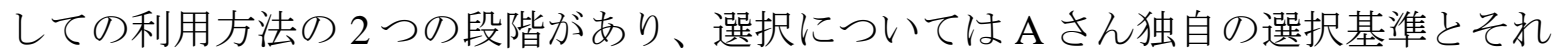
に基づいた分類がある。次に、放送主としての利用であるが、これは実際に Aさん 自身が発信者となりゲームの解説を行うというものである。視聴者としての利用し 
SiSAL Journal Vol. 9, No. 2, June 2018, 179-195.

始めたのは日本語学習を始めた 15 歳のころからで現在も続けて視聴している。日本 語学習も意識して視聴していたのは大学に入るころまでで、週に $3 、 4$ 回は視聴し ていた。放送主として利用し始めたのは、視聴を始めた 1 年後の 16 歳からであり、 これをきっかけに日本語を話すようになった。放送主としての利用は不定期であっ たが、平均すると週に 1 度は行っており、現在でも頻度は少ないが利用していると いうことである。つまり、ニコニコ動画を使い始めて 1 年間は視聴のみのであった が、その後は視聴と放送という 2 つのパターンでニコニコ動画を利用するようにな り、現在も継続している。

\section{動画や生放送の視聴者としての学習の進め方}

次に、視聴者としての学習の進め方について、動画や生放送の選択とそれを 用いた学習方法という 2 段階に分けて説明する。視聴者として利用する際には、ま ず動画や生放送を選ぶ必要がある。以下に、Aさんによる動画や生放送の選択の基 準と教材としての分類について解説する。

教材として用いる動画や生放送の選び方とその分類 ニコニコ動画のサイト には無数の動画がアップロードされて生放送も行われている。以下に、日本語学習

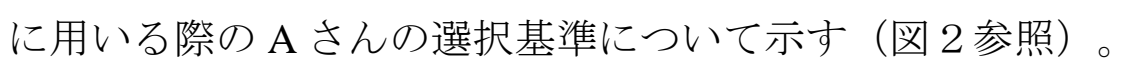

1. 話される日本語のレベル：ゲームの種類や内容によって使用語彙や発話の長さ が変わる。

2. 日本語の字幕の有無 : 字幕に使われる漢字が漢字圈出身の A さんにとって理解 の助けとなる。

3. 放送主の話し方 : 低音の声で話し方がゆっくり、かつ、抑揚の少ないものが聞 きやすい。

上記のような基準をもとに、Aさんは動画を初級、中級、上級と分けてい る。まず、ゲームの内容であるが、アクションゲームは初級に、ストーリー性の高 いロールプレイングゲーム（RPG）はレベルが高く中級から上級に分類される。ア クションゲームが初級である理由としては、ゲームの解説として出てくる日本語に 
SiSAL Journal Vol. 9, No. 2, June 2018, 179-195.

は、「あ」や「あ〜あ」、「落ちた」「死んだ」といったような短く簡単な感嘆詞 や動詞が多いことを理由として挙げている。また、アクションゲームは、ストーリ 一が決まっているため、ゲームの進行に関する説明が少なく、あったとしても比較 的理解が容易であるという。一方、中級以上に分類される RPG は、『バイオハザー ド』のようなホラーゲームはアイテムの説明が多少難解ではあるものの、ゲームの 進行に関しては敵を倒すことが中心であることもあり、叫び声が多く理解しやす い。その一方で『絶体絶命都市』のような RPG では、プレーヤーが問題を解決する 必要があり、それによってゲームのストーリー展開を変えたりすることもあるた め、語彙量が多く解説も長くなりがちで聞き取りも難解になるということである。

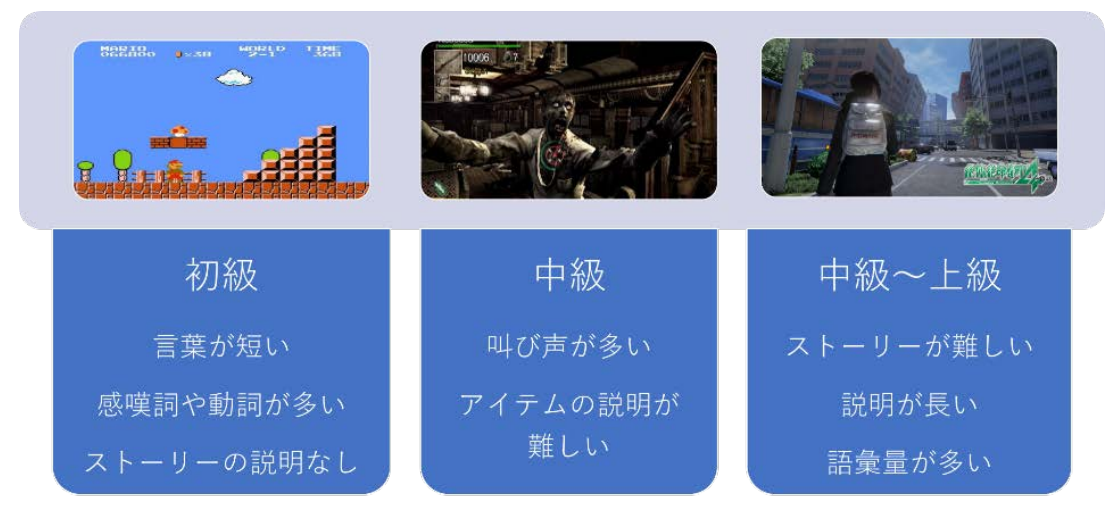

図 2 : 教材としてのコンテンツの分類

『（4倍速）スーパーマリオ』を用いた学習方法 まず、実況動画を用いた 学習の基本的な方法について概説する。

「ゲーム解説はたくさんあって、コンテンツ。それを見るリスナーをたくさ んいる。コンテンツはレッスンみたいで、そこでたくさんの日本人がコメント付け ています。これは全部がまるでテキスト。分からないときはグーグル先生にコピペ します。」 
SiSAL Journal Vol. 9, No. 2, June 2018, 179-195.

A さんは動画や生放送を作成者や生放送の放送主によるゲームの解説と視聴 者のコメントを通して行われる両者のコミュニケーションすべてを日本語の教材と して捉え、話される日本語やコメントに使われる漢字や Google 翻訳を学習ツールと して用い理解を進めていた（図 3 参照）。

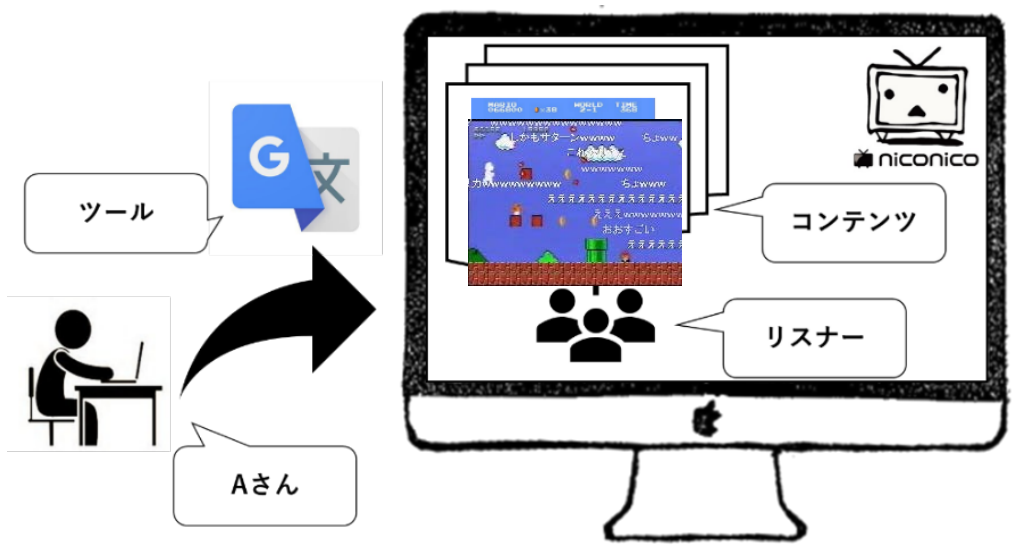

図3：ニコニコ動画を介した日本語学習

次に、『（４倍速）スーパーマリオ』の生放送を例に、具体的な学習方法に ついて紹介する。

「コメントがでるので、画面とコメントを見て、考えます。分からないとき はコピーして Google で調べて。漢字が出たら分かりやすいですが、でも、なんか漢 字がないときもあります。例えば、落ちたときに、空耳とかありますよね。例え ば、ポア、アホーとかしやべりながら、みんなのコメントで、ポアという日本語を 幾つも漢字を当たって、そうするとまずそこで勉強する。ポアは漢字がなくても、 ネットで説明があるので（分かる）。あと、コメントとか Google でも意味がない音 のときは難しいですね。でも、あ、これは音ですねと画面を見て分かる。」 
SiSAL Journal Vol. 9, No. 2, June 2018, 179-195.

視聴時は Google 翻訳を用いるが、マリオが落ちていく音を表現したものや辞 書に記載がないものは、Google 翻訳では示されない。そのためインターネットで検 索をし、画像との関連で意味を推測していく。また、Aさんは、画面から情報を受 けとりそれを理解することに努めるだけではなく、そこで行われているやり取りに 参加するようにもしていた。

「最初は、記録がありますので、最初調べたけど、最初は点が一つだけ。謎 のコメント。多分テストみたいな感じ。押したかもしれない、私。押したんだ。謎 のコメント送ってたんだ。その次は、『w』（笑いを示す記号）って押してたん だ。面白い。それで参加するようになって。そのときは、すごく緊張した。あと、 『あ』。例えばマリオが落ちたときに、『あ』みたいに。（中略）みんながコミュ ニケーションして、私も参加する感じです。」

$\mathrm{A}$ さんは点や $\mathrm{w}$ といったアルファベットから発信を始めた。そして、他のリ スナーが送るコメントを模倣して自身も送信することで、そこで行われているコミ ユニケーションにも参加するようになった。

\section{生放送の放送主としての学習方法}

次に放送主としての学習方法について記述する。Aさんは上述のようにユー ザーとして視聴し、コメントに参加するだけではなく、実際に発信する側としても 参加するようになった。そして、さらには Aさんも『絶体絶命都市』の実況中継を 自身で行うようにもなった。次に放送主としての学習方法について具体例をもとに 解説する。

『絶体絶命都市』のゲーム実況を通じた学習方法 まず A さんは実況動画を 始める前に、ある人物の動画やサイトを見て、それを自身の生放送のデルとして利 用していた。

「私、友達が実況見始めたのは、台湾のブログで、そういう日本の実況動画 を紹介するサイトがあって。後で、ブログで、その動画どうして面白いか、幾つ紹 
SiSAL Journal Vol. 9, No. 2, June 2018, 179-195.

介するので、その動画面白いな多分、なのでクリックした。多分、コメントと実況 する人、やり方。ちょっとチェックして。コメントが面白いかな。（中略）だから いつもチェックして、この人のようにやっていました。こんなときはどうしてるの かなとか見て自分でもやってみる。師匠みたい。」

この「師匠」と呼ぶ人物が使う語彙や表現を書き留め、自分自身が放送する ことを想定したリハーサルを行い、実際にオンラインで生放送を行っていた。

「大体、1回放送をやったら、自分の心の中で反省会が開かれる。（中略） 流ちょうではない、しやべっているときに、ずっと止まっている、止まっていると はどうしてだろうって。あとは単語が思い出せない。これを後で反省会で考え直 す。そして、もう一回、生放送する。たまに自分、本当に、生かしてやってない な、本当に気になったときあったんですけど、自分の音を聞いて録音して。」

以上のように、Aさんはよりよい放送をするために、生放送後に「反省会」 を開き、録音しておいた自身の生放送を振り返る時間を設け、次の対策を考えてい たと述べている。

「コメントにひどいのとかも来ましたよ。コメントで「ひどい」って言われ てることがありました。何を言ってるのか分からないって。発音がひどいって。だ から実際に発音をもらって練習したり。発音が通じるようにならなきやって。聞い てもらえないですよね。そうしたら、生放送する時間帯を夜にする。2 時とか。そ う。多分あの辺、ゲームに来る人が少ないし、優しい人とか。男性のほうが多いと 思いますけじ。多いですね。その人たちのほうが、優しいっていうか、気にせずに コメントしてくれる。」

また、振り返りにはユーザーからのコメントも利用していた。上記の発言に もあるが、生放送は日本語学習者であるからという配慮など一切ない場であり、A さんにとっては非常に過酷な状況であったことが予想される。Aさんは少しでもそ の状況を緩和するために放送時間を遅くすることで参加人数を減らすなどの工夫を 
SiSAL Journal Vol. 9, No. 2, June 2018, 179-195.

行っていた。生放送を実行し、反省会を開き、発音や表現に関してユーザーからも らったコメントを振り返ったり、生放送後にファンと雑談したりすることで分かり にくかったところなどのフィードバックをもらうこともあったということである。

このように、Aさんは生放送の時間を変えるといった調整を施しり、親しく なったリスナーからのコメントを次回の生放送に活かしたりしながら、生放送を続 けてきた。

\section{考察}

以上が A さんの学習経験であるが、その経験を分析すると、まず、ニコニコ 動画が実践共同体として、また、セルフアクセスラーニングスペースとして機能し ていることが窺える。まず、実践共同体であるが、Aさんが利用していた動画や生 放送は、情報収集などを目的としたユーザーが集まりコメント機能を利用しながら ゲームに関する知識を深めていくという場であると捉えることができる。また、A さんはゲームに関する実践への参加を通して日本語を学んでいるが、自分に合う動 画や生放送を選択したり、自身の放送内容の内省を行ったりするなど、学習に関す る意思決定を行う学習者オートノミーを発揮しながら日本語学習を進めていたこと が分かる。Aさんにとって、ニコニコ動画は、目的に合ったタスクや教材が選択で きるセルフアクセス（Sheerin, 1991: 143）と日本語を用いた実践が可能なセルフアク セスラーニングスペースとしての機能も有していたと考えらえる。

次に、ニコニコ動画の実践共同体としての機能や学習者オートノミーを促進 するセルフアクセスラーニングスペースとしての機能という 2 つ視点から考察す る。

\section{日本語学習を伴う実践共同体としてのニコニコ動画}

まず、ニコニコ動画の実践共同体としての側面について考える。

SNS と日本語学習の関連についての先行研究では、教室学習の一部にSNS の一つで ある Facebook を取り入れることで、自律的かつ創造的な学習活動が起こったことが 報告されている（Nakai, 2016）。これは、Facebookによる学習活動が、学習者に学 習そのものの所有意識をもたらし、教室という切り取られた場での学習活動を彼ら の生活世界に位置付けたためである。Nakai（前掲）で見られたこの Facebook での 
SiSAL Journal Vol. 9, No. 2, June 2018, 179-195.

学習活動は、Facebook グループというクラスメートで構成された閉じられたグルー プの中で起こったものであった。それに対して、Aさんはニコニコ動画で自身の興 味関心に基づいた動画を選択し、それに集うユーザーたちとつながっていた。言い 換えれば、ニコニコ動画は、様々な不特定多数のユーザーによって配信された動画 の保管庫で、それを視聴するユーザーが存在する開かれた世界とつながっているの である。また、ゲームをプレイすることで語彙や表現を覚えたり、学習目的に合わ せてゲームをしたりする例が報告されているが（Chik, 2011）、Aさんの場合、自身 がゲームをプレイすることよりも、ゲームの攻略をみんなで楽しむ、あるいはその 攻略方法を知ることが目的であった。そして、それらの目的を持った人たちによる 実況動画や生放送の中でのやり取りを理解しコメントを発信したり、自身が実況動 画の放送主となったりすることで必要な日本語を身につけてきた。例えば、Aさん は『絶体絶命都市』の実況動画を視聴しているが、Aさん自身も楽しんでいたその ゲームの攻略法を知るために、その情報が提供される場に参加していた。そして、 その情報を理解するために、そこで用いられている日本語を、画面から得られる情 報やグーグル翻訳を駆使して解読していたと見ることができる。つまり、Aさんに とって、ニコニコ動画はゲームの攻略方法に関心を持った人たちが集い、動画や生 放送を通じてそれを共有する実践共同体であり、ゲームに関する情報を収集すると いう実践への参加を通して日本語学習が起こっていたと考えられる。

\section{学習者オートノミーを促進するセルフアクセスラーニングスペースとしてのニコニ コ動画}

次に、学習者オートノミーを促進するセルフアクセスラーニングスペースと しての観点からニコニコ動画の機能を考察する。Aさんの学習の進め方を見ると、 次のようなプロセスが見られる。まず、動画や生放送を Aさんなりの基準で日本語 の難易度を設定し、自身のレベルに合ったものを選択している。次に、Aさん自身 が発信する生放送にあたっては、ロールモデルとなる台湾のユーザーの動画を参考 に生放送を実践した後、録音した実践やユーザーからの反応を振り返ったりするな ど、実践後に内省を行っている。そして、その内省に基づき、生放送での発言内容 を修正したり、生放送の時間帯をリスナーの少ない深夜の時間帯に变えたりするな ぞ、生放送の方法に修正を加えている。このプロセスを伴う学習は「学習の目的、 
SiSAL Journal Vol. 9, No. 2, June 2018, 179-195.

目標、内容、順序、リソースとその利用法、ペース、場所、評価方法を自分で選ベ る」（青木・中田, 2011: 2）能力である学習者オートノミーが発揮された状態である と見ることができる。さらに、Aさんはコンテンツを自分の能力に合う物を探し出 す、つまり自分の言語能力を相対的に知っていて、それに見合った内容のコンテン ツを選び出しているが、これは A さんのメタ認知能力が高いことの現れであると言 える。Benson（2011）によると、学習者オートノミーは、学習の運営、認知的なプ ロセス、学習内容という3つの側面をコントロールする能力であり、特に認知的な プロセスのコントロールについては、タスクを達成するために必要な状況を把握 し、それに見合うように現状を調整できることであるとされている（O’ Malley and Chamot, 1990: 138）。したがって、A さんの学習プロセスは、Aさんの学習が認知的 なプロセスをコントロールする学習者オートノミーが発揮されたものであることを 示していると考えることができる。

しかし Aさんがこのような学習を進めることができたのは、もちろん Aさん 自身の能力もさることながら、ニコニコ動画が持つ実践共同体としての特徵も影響 を与えていると考えられる。ニコニコ動画には、コンテンツを選ぶ、視聴するかど うかを選ぶ、生放送にコメントをする、つまり参加するかどうかを選ぶという選択 の自由がある。また、参加度についても、一視聴者として見るだけという周辺的な 参加であったり、コメントを発信する、あるいは自身が放送主になるといった中心 的な参加もある。コンテンツの豊富さとその選択や参加を妨げないニコニコ動画の 環境は、Aさんの学習者オートノミーという能力を育み発揮を促していたと見るこ とができるのである。

\section{まとめ : バーチャルなセルフアクセスラーニングスペースとしてのニコニコ動画}

以上、ニコニコ動画を用いた学習とニコニコ動画が持つ特性について考察し た。ニコニコ動画は実践共同体としての特徵を備えており、選択や参加の自由が保 障されている場であると同時に、オートノミー育成と発揮に親和性の高い場である ことが分かった。Murray（2018）によると、社会的なスペースとしてのランゲージ カフェは、学習を促進し、人的ネットワークを構築するアフォーダンスを備えてお り、学習者には学習へのアクセスのしやすさから学習との接点が生まれやすい。ま た、人とのつながりがサポートになるだけではなく、なりたい自分を築いていくき 
SiSAL Journal Vol. 9, No. 2, June 2018, 179-195.

つかけをもたらすと分析している。Aさんの経験を見ると、ニコニコ動画には、ゲ 一ム実況という実践を可能にする様々な機会が提供されている。また、生放送など を通じて人とのつながりを築いたりゲーム実況のロールモデルを見つけたりするこ ともできる。つまり、ニコニコ動画という場は、インターネット上にあるバーチャ ルな空間ではあるが、Murray（前掲）の指摘する特徵を備えたものであり、バーチ ヤルな社会的学習スペースであると言える。学習のデザインとは、自分がどうなり たいのか、どういうところに所属したいのか、またそれを可能にするためにはどの ような実践をするのか、そしてその実践によ゙んな意味づけをするのか、というよう に学習の目的と意味を見出していくことであるとされており、生涯学習へとつなが るための重要な要素である言われている（Deakin Crick, 2014）。今回の研究では、A さんには過去の学習経験の中で思い出せない部分があった。それに加えて、ニコニ コ動画での学習場面を実際には観察していないため、Aさんの経験を全て忠実に記 述できたとは言えない。しかし、これらの点を踏まえ、ニコニコ動画を用いた学習 経験者についてのさらなる調査や実際の学習場面の観察などによる分析を進め、ニ コニコ動画のような SNS が持つバーチャルなセルフアクセスラーニングスペースと しての機能について検討することは、日本語に直接触れる機会が少ない JFL 環境に おける日本語学習や生涯学習を見据えた継続可能な自律学習を考える上で非常に意 義があると言えるだろう。

\section{Acknowledgments}

本研究を進めるにあたり、インタビューにご協力してくださり、貴重な経験につい て語ってくださった Aさんに改めて感謝を申し上げたいと思います。また、この研 究は JSPS 科研費 JP17K02874 の助成を受けたものです。

\section{Notes on the Contributor}

同志社大学日本語日本語文化教育センター助教。大阪大学大学院文学研究科にて博 士号 (文学) を取得。日本語教育に携わっており、学習者オートノミーやアイデン ティティをテーマとした質的研究を行っている。 
SiSAL Journal Vol. 9, No. 2, June 2018, 179-195.

\section{References}

青木直子・中田賀之 (2011).「学習者オートノミー一初めての人のためのイントロダ クションー」青木直子・中田賀之編『学習者オートノミー一日本語教育と外 国語教育の未来のために一』序章, ひつじ書房, 1-22.

Benson, P. (2011). Teaching and researching autonomy (2nd ed.). New York, NY: Routledge.

Benson, P., \& Chik, A. (2010). New literacies and autonomy in foreign language learning. In M. J. Luzon, M. N. Ruiz-Madrid, \& M. L. Villanueva (Eds.), Digital genres, new literacies and autonomy in language learning (pp. 63-80). Newcastle, UK: Cambridge Scholars.

Benson, P., \& Reinders, H. (Eds.). (2011). Beyond the language classroom. London, UK: Palgrave Macmillan.

Chik, A. (2011). Learner autonomy development through digital gameplay. Digital Culture and Education, 3(1), 50-64.

Chik, A. (2018). Learner autonomy and digital practice. In A. Chik, N. Aoki, \& R. Smith (Eds.), Autonomy in language learning and teaching: New research agendas (pp. 7392). London, UK: Palgrave Macmillan.

Cross, J. (2007). Informal learning. San Francisco, CA: Pfeiffer.

Deakin Crick, R. (2014). Learning to learn: A complex systems perspective. In R. Deakin Crick, C. Stringher, \& K. Ren (Eds.), Learning to learn: International perspectives from theory and practice. Abingdon, UK: Routledge.

Gee, J. P. (2004). Situated language and learning: A critique of traditional schooling. New York, NY: Routledge.

Kárpáti, A. (2009). Web 2 technologies for net native language learners: A “social CALL”. ReCALL, 21(2), 139-156. doi:10.1017/S0958344009000160

Murphey, T., Chen, J., \& Chen, L. C. (2004). Learners' constructions of identities and imagined communities. Learner's stories: Difference and diversity in language learning (pp. 83-100). Cambridge, UK: Cambridge University Press.

Murray, G. (2018). Researching the spatial dimension of learner autonomy. In A. Chik, N. Aoki, \& R. Smith (Eds.), Autonomy in language learning and teaching: New research agendas (pp. 93-113). London, UK: Palgrave Macmillan.

Nakai, Y. (2016). How do learners make use of a space for self-directed learning? Translating the past, understanding the present, and strategizing for the future. Studies in SelfAccess Learning Journal, 7(2), 168-181. Retrieved from https://sisaljournal.org/archives/jun16/nakai/ 
SiSAL Journal Vol. 9, No. 2, June 2018, 179-195.

Nunan, D., \& Richards, J. C. (Eds.). (2015). Language learning beyond the classroom. New York, NY: Routledge.

Peeters, W., \& Ludwig, C. (2017). 'Old concepts in new spaces’: A model for developing learner autonomy. In M. Cappellini, T. Lewis, \& A. Rivens (Eds.), Learner autonomy and web 2.0 (pp. 115-140). Bristol, CT: Equinox.

Prensky, M. (2001). Digital natives, digital immigrants part 1. On the Horizon, 9(5), 1-6. doi:10.1108/10748120110424816

Sheerin, S. (1991). State of the art: self-access. Language Teaching, 24(3), 43-157.

Wenger, E., McDermott, R., \& Snyder, W. M. (2002). Cultivating communities of practice: A guide to managing knowledge. Boston, MA: Harvard Business School Press.

やまだようこ (2000).「人生を物語ることの意味 : なぜいまライフストーリー研究 か?」『教育心理学年報』39, 152. 